\title{
The Muslim Brotherhood's Gender Agenda: Reformed or Reframed?
}

\author{
Mariz Tadros
}

\begin{abstract}
The Muslim Brotherhood (MB) has been hailed as an example of a reformist Islamist movement whose role is key to the democratisation process in Egypt. This article examines the extent to which first, the Muslim Brotherhood's agenda has been reformed, and second, the extent to which it recognises women's full and equal citizenship and third, the interface between agency and ideology. The multiple standpoints on gender matters existing within the movement is more than a manifestation of heterogeneity; its political function is to enable the movement to adopt different faces (framings) for multiple audiences. The article argues that the fundamental gendered construction of division of roles and power has not been reformed but reframed through the instrumentalisation of various discourses, despite the active agency of women in support of the movement.
\end{abstract}

\section{Moderates in the eye of the beholders}

In the post-9/11 context, the term 'moderate Islamists' has come to be very much in vogue. Many think tanks and scholars of Islam and democratisation in the USA in particular, have promoted a policy of Western engagement with moderate Islamist movements in the Middle East (The Carnegie Endowment for International Peace, The Centre for the Study of Islam and Democracy; Brown et al. 2006; Hamid 2007; Ibrahim 2006; Wickham 2002). Moderate Islamists are defined as those who 'reject violence and endorse competition through pluralistic politics' (Hamzawy 2005: 2). It is a form of labelling that pro-Islamist movements sympathisers inside the Middle East have adopted. The Muslim Brotherhood (MB), one of the movements that was labelled 'moderate' in accordance with the definition cited above, is presenting itself in those terms on its English website, ${ }^{1}$ presumably for a Western audience, since this does not feature on the Arabic website.

There are several arguments formulated in favour of an inclusive policy towards 'moderate' Islamists. The first is that as movements that denounce violence as a means of accession to power, they present a counterweight to the extremist radical Islamists, and therefore represent the kind of political forces that should be promoted as versions of the 'reformist' Islam. Second, is that no democratisation in the Middle East is viable without the inclusion of 'moderate' Islamist parties, since they hold much popularity on the street which neither authoritarian regimes nor secular political parties and movements can claim. In Egypt, the results of the parliamentary elections of 2005 signalled that the Muslim Brotherhood were the most organised political force with wide appeal that could seriously compete with the ruling party, the National Democratic Party. While the majority of Egyptians did not vote, the Muslim Brotherhood was still able to win enough votes to secure 20 per cent of the seats in parliament. Third, is that they represent the potential for progress and reform within the Islamic movements in particular in view of their flexibility and more sophisticated thinking (Brown et al. 2006: 19).

This article examines the extent of flexibility and reform characterising the Muslim Brotherhood's contemporary engagement with the gender agenda - an agenda that cannot be detached from the wider democratisation agenda. Since such an agenda is very broad and issues are historically contextual; the focus here is on gender roles and division of labour and women in power, leadership and politics. ${ }^{2}$ To do so, the position of Hassan al-Banna ${ }^{3}$ on key 
issues, was compared with the positions of the current leadership published in the most recent official documents and is complemented with interviews with members of the movement and some ethnographic work.

The article makes three postulations. First, that the ambiguity over what represents the movement is a political strategy deployed to maximise manoeuvring space, to allow the Muslim Brotherhood to represent itself as some very different things to diverse parties. Second, the repression at the hands of the government has served to divert attention from some internal matters, gender inequalities being one of them. Third, that those highly regressive gender norms in society and the weakening of social forces with progressive gender agendas (such as the feminist movement) means that the Muslim Brotherhood is not under pressure to reconsider, justify or be held accountable for gender discriminatory stances.

\section{Representation, voice and methodological conundrums}

Despite the fact that the Muslim Brotherhood was established as a civic association (nongovernmental organisation, NGO) in 1928 by Hassan al-Banna, it quickly developed from a strictly religious organisation proselytising adherence to true religious values to one with a political and social vision for Egypt. Rashwan (2006) identifies the time since the conception of the Brotherhood up to the late 1940 s as a time of building the foundation and outreach. An important historical turn in state-movement relations from 1951-4 ended with a great confrontation between the Muslim Brotherhood and the Nasserite government and signalled the beginning of the systematic repression of members of the movement. Under the new leadership of President Sadat, the movement entered a 'rebirth' as it witnessed the release of imprisoned members of the MB. This was part of a strategy of strengthening the Islamist movement in Egypt in order to contain the perceived 'communist threat' emanating from groups that were sympathetic to Nasser's socialist beliefs, and communist and Marxist leaning groups. It was in that political and economic context, in which Sadat adopted an open market policy characterised by the state's retreat from free welfare provision, that the Muslim Brotherhood movement was revived.
During this historical period, they successfully reached out to the middle-class that formed its new rank and file (after the previous membership had all but dissolved under the Nasserite government) and that were to occupy key policy and decision-making positions in the government and civil society organisations (Rashwan 2006: 41).

The assassination of President Sadat in 1981 at the hands of a member of the more radical and militant Islamist group, Jihad, brought President Mubarak to power in the same year. Rashwan characterises the Muslim Brotherhood's relationship with the government under the Mubarak regime as undergoing three stages. The first is from 1981-8, in which the government treated the movement with clemency and tolerance, and which enabled the Brotherhood to build a populist base, especially through its much needed social services and benefits that were extended to a population that did not share in the wealth accumulated by a small class of entrepreneurs under the open market economy. From 1988 to 1992, the Brotherhood's relationship with the government began to sour as the latter's suspicions and fears were heightened when faced with the scale of Brotherhood activity and membership and in the light of the movement's lack of condemnation of the militant Islamist terrorist attacks on tourists and government figures (Rashwan 2006:42).

From 1993 to the present, relations have been characterised by confrontation, and the authorities have pursued a policy of repression, detaining leading figures and members of the movement. Although officially outlawed, the movement is allowed to exist on the political landscape and has been actively engaged in the political process (Choubaky 2006).

Organisationally, the Muslim Brotherhood is led by the Supreme Guide and supported by the Guidance Bureau, the political bureau which is elected by members of the Shura (majlis al Shura: Consultative Council). There is a highly elaborate structure on the ground, regulating relations among rank and file. The Muslim Brotherhood also has its own Mufti which issues fatwas (religious opinions) for its members.

Like other religious/political movements, the Muslim Brotherhood is not a uniform political group, and is the site for power struggles between 
different factions representing different ideological positions. Some have argued that the power struggle lies between the Old Guard representing the conservative elements and the reformists who tend to be younger in age. The difference in position between members from the more conservative and the reformist elements can sometimes, as will be shown below, suggest that two contradictory positions are being articulated, and both claim to be legitimately representing the Muslim Brotherhood.

The author sought direction from the former Supreme Guide Muhammad Mahdi Akef, as well as other members of the Guidance Bureau on the methodological approach to pursue in order to arrive at a legitimate representation of the Brotherhood. A virtually unanimous opinion is that any official endorsement by the Supreme Guide should be taken as the authoritative, undisputed source of reference on the Muslim Brotherhood's viewpoint, i.e. the writings that have resala min al ikhwan (message from the Brothers) inscribed on it. In addition to these, a number of official documents are considered representative. The methodology relied on the examination and analysis of a series of sources. First, Hassan al-Banna's main work on the subject in view of his central role as the founder of the movement and first supreme Guide and in order to gain an understanding of the position of the Muslim Brotherhood at its conception and until his death in 1949. Second, the official documents published, such as Al-Mubadara in 1994, the party election agenda published in 2006 and more recently, the party platform published in 2007. ${ }^{4}$ These were however, complemented with interviews with key women leaders within the movement as well as prominent members of the Guidance Bureau in 2008. Earlier political ethnographic work conducted in a poor squatter settlement of Cairo also shed light on elements of agency, and perspectives from the rank and file.

Many members of the movement insisted that other than the official documents, no single person's views could be considered as representing legitimately the views of the movement as a whole and could only be considered to speak for herself/himself. The restriction of official representation to a number of generic documents, and making all other sources open for contestation allows the Muslim Brotherhood to pursue a political strategy that entails relaying different images of itself to different audiences. For example, to the Western world and Western-affiliated scholars, leaders from the reformist wing such as Abd el Moneim Abou el Fotouh and Essam el Erian conveys a highly progressive image of the Brotherhood, yet their views on women's rights is unrepresentative of the majority of the members of the Guidance Bureau and rank and file. ${ }^{6}$ And to members raised in the pedagogical training of the Muslim Brotherhood to become the movement's rank and file, their engagement would be with the writings of Sheikh Yusuf al-Qaradawi, Sheikh Mohammed al-Ghazali, Dr Mohammed Ghozlan, al Baheyi Al Kholi, Tawfik al Wa'i, Abd el Mota'al Al Gabry, Mustafa al Seba'i, Abd el Halim Abou Shouka and Salem Al Bahnasawy who for the most part carry very different viewpoints on gender issues than the reformists. And to members of the Muslim Brotherhood who have particular queries on particular matters, there is also the mufti, whose fatwas are relayed through other channels.

\section{Gender roles, the public and the private}

Hassan al-Banna highlights his views on the position and role of Muslim women in a rare article published in 1940 entitled 'resalet al mar'a al muslima' addressing the members of the MB. The basis for writing the resala, explained alBanna is the need to remind believers of the decrees of Islam on women's role in society in the light of what he sees as the Muslim world's bid to emulate the West, a quest which has led them to seek ways of conforming the decrees of Islam to European orders and ways. 'In reality, this country [Egypt] and other Islamic countries have come under the shadow of a revolutionary and vicious wave', he writes, explaining that this wave is, 'the love of emulating Europe and immersing itself in it right to the chin' (1980: 4). He reflects that those that wish to be like the Europeans have not stopped there, 'but they try to deceive themselves by twisting the laws of Islam according to their Western liking and European orders/systems and to take advantage of the leniency of this religion [Islam] and the flexibility of its laws' (1980: 5). According to alBanna, such manipulation of Islamic texts, 'totally removes these laws from its Islamic form and transforms [these laws] into other orders/systems that have nothing to do with it [Islam] under any circumstance. They totally ignore the spirit of Islamic jurisprudence [and 
they also ignore] many of the texts that do not agree with their liking' (1980: 5). Hassan alBanna sees this is as doubly dangerous, since it is not enough for them to deviate but that:

they try to find legal justification for this and they try to cover it up with pretence of it being halal [religiously sanctioned] and permissible ... What is important now is that we examine the decrees of Islam with a view devoid of our personal inclinations, and prepare ourselves to accept Allah's orders especially in this matter which is crucial for our contemporary renaissance. (al-Banna 1980: 6)

Al-Banna broaches issues that were the subject of intense debate at the time of the formation and spread of the Brotherhood: women's entry into tertiary education to study sciences and humanities, gender segregation being challenged and the increased visibility of women in public, urban spaces. Hassan al-Banna makes three principle arguments in his article, the first relating to women's status in Islam, the second addresses the religious premise behind the division of gender roles according to sex, and the third, the attraction between the opposite sexes and its role in preserving the complementarities in roles between men and women according to their sex. The first point relating to Islam's valuation of women is briefly broached in one paragraph. Hassan al-Banna affirms that Islam has elevated the status of woman, and recognises her as a partner to man in rights and duties. In the second point, he qualifies the earlier statement by contending that the difference between man and woman in rights is attributable to their different natures and in accordance with the different roles assigned to each (1980: 7). This differentiation of roles according to sex, he affirms, is also for the maintenance of the rights granted to each. In that, he suggests that where men were given more rights, women were compensated for this in other areas. He emphasises that this division of roles is derived from their biology/nature. This strict prescription of well defined gender roles based on biological differences guides the rest of the article vis-à-vis women's role in a Muslim society. The implications of these gender divisions of roles are described under the rubric of the need for preserving a particular order between men and women, and for which the rest of the article is dedicated.
Women's exit into the public arena for other more worldly purposes is rejected by al-Banna as anathema to Islam and its decrees:

This fascistic ${ }^{8}$ mingling of sexes among us in schools, institutes and public gatherings and their going out to places of entertainment, restaurants, parks ... all of this is foreign goods which have absolutely no relation to Islam and has had the worst effects in our social life. (al-Banna 1980: 18)

He refutes the argument that there is no Islamic text/verse to prohibit women from engaging in public works, arguing that just because there is no verse against hitting parents, it does not mean that it is permissible. Al-Banna recognises that under some 'social circumstances' a woman goes out to work, but if this occurs, he warns that first, women must adhere to the conditions mentioned above (re: appropriate attire revealing only palms and face, etc.) and that it is a duty for her that her work be within the dire necessities, and 'not as a general rule/ organisation that it be for a woman to have a right to work in principle' (1980: 21).

Today, the official framing of ideas on gender roles espoused by the Muslim Brotherhood in relation to gender issues is very different from that of al-Banna's rhetoric. However, the essence of the message vis-à-vis gender roles bears a striking resonance to Hasan al-Banna's exaltation of women's role as mothers and wives, especially in terms of the reference to the 'noble task' and 'noble mission' and in its presentation of the domestic realm as a sanctuary where she exercises her lordship and power. For example, the Muslim Brotherhood's election platform of 2006, states that:

We must not forget that the woman has a noble and significant task entrusted to her by Allah Almighty, child-bearing and motherhood. A man cannot undertake this most noble of tasks, which is being denigrated today by some; furthermore the human race itself would disappear in the absence of this process. Moreover, it is the mother that suckles the baby with her milk, giving out of care, nurturing the child, the effects of which remain with him throughout his life. The woman is also the mistress of the house (rabat al bayt) and it is her task to care for the family 
and prepare the home as a place of comfort; her role is a huge responsibility and noble mission that must not be in any way neglected or underestimated. (Muslim Brotherhood 2006a)

While the official statement of January 2006 does not go specifically into the limitations and conditions of work outside the home, as is the case with Hassan al-Banna's earlier message, it nevertheless reveals not only the undesirability of work for women, but also the need for regulating woman's work. A woman can work only if given permission by her husband. According to the statement:

These characteristics, duties and rights which have been allocated to women by Allah are in balance with the duties she has towards her husband and her children. These duties must be given precedence over other responsibilities and they are necessary for the stability of the family which is the basic cell of the society and the cause for its cohesion, strength, and efficiency. However, the husband has a right to permit his wife to work. This right is to be regulated by an agreement between the husband and the wife. Such rights should not be regulated by law and the authorities should not interfere with them except in some rare cases. (Muslim Brotherhood 2006a)

In other words, on a policy level, the Muslim Brotherhood is opposed to any constitutional guarantee of women's right to work as citizens. While the statement talks about the 'regulation' of men's right to permit his wife to work through agreement between them, it is ultimately the man who has the right to allow or prohibit his wife from working. The draft Party Platform of 2007 discussion of the issue of women's roles and the question of work reflects more Mohammed Habib's framing of the argument in terms of complementarity of roles.

The 2007 Platform argues that although women's role in the workforce is to be recognised, such a role has to be 'balanced with the noble mission that a woman bears in her home and among her children for the sake of the uprightness of the first foundations of society' (2007: 103). The remaining paragraph, however, does not talk about complementarities between women's home and work roles; rather, it provides a typical Muslim Brotherhood justification for a woman's association with the domestic, premised on her biological nature and the division of roles deriving from it. The Platform argues that while the Muslim Brotherhood recognises women's full equality with men in their humanity, nonetheless, there needs to be an emphasis on:

... the importance of preserving the distinction between them in social and human roles, without this affecting the status of each of them. The role of women in the family is founded on the premise that she holds the primary/main responsibility for raising the new generation ... consequently we believe in the importance of finding balance in the roles of women and reviving her role in the family and public life without imposing on her duties which conflict with her nature or with her role in the family. We believe that the roles that women [should] espouse are an outcome of a social consensus built on the Islamic civilisational terms of reference (marja'iyya). (Muslim Brotherhood Platform 2007: 103)

Of significance here, is the use of the language of protection: refraining from imposing duties outside her nature, the language of democracy: roles should be based on a social consensus which derives its premise from an Islamic reference point, etc. While individual women within the movement have deviated from the above model (such as Zeinab el Ghazali below), this position is not merely an ideal, it reflects the dominant discourse and stance, one which has much currency among both men and women in the movement, despite some generational variation.

\section{Power, politics and leadership}

Hassan al-Banna's position on women's political activism was largely shapely by his belief in a clear gender division of roles in which women's domestic responsibilities take centre stage. Consequently, when in 1944 the Egyptian parliament was debating whether to grant women the right to vote or not (and which they voted against), Hassan al-Banna's position was negative towards the whole women's right to vote campaign, believing that it was intended to divert women's attention from her principle role in the family as a mother and as one entrusted with the raising of the children (El Deiry 2007: 323). Women members of the Muslim 
Brotherhood were active politically in support of the movement, as were their counterparts in other political movements, yet women's full political rights were only officially recognised in 1956 when Egypt achieved universal suffrage following a long struggle led by the Egyptian feminist movement. ${ }^{9}$ However, the question of gender and political leadership became politically salient in the $1970 \mathrm{~s}$, and many writers within the MB movement began to engage with it. Among the most notable was the then Mufti of the movement, Sheikh Abd Allah el Khattib, who insisted in a fatwa that the principle of Qawãmah (leadership or guardianship) was not only reserved for men in the private sphere but in the public as well. ${ }^{10}$ The Brotherhood's Mubadara later argued that:

The boundaries of men's qawãmah over their wives is restricted to marital partnership only and it is a qawãmah of sincerity and mercifulness and consultation in return for responsibilities born[e] by the husband. ${ }^{11}$

Leading women members of the MB such as Helmy have framed men's qawãmah over women in terms of human rights: 'We raise the banner of men's qawãmah as a right for woman and not for man', she affirmed, explaining that it is men who are required and obligated to earn a living and provide for the household and not the woman. ${ }^{12}$ The fact that a woman is not required to earn her bread is for Helmy one of the privileges accorded to women as a result of men's qawãmah. In practical terms, while Helmy talks about men's obligation to provide for the household as a woman's right, there are a plethora of personal and economic factors that would prevent a man from being able to provide for his family (such as unemployment) and for which it would be difficult for women to hold them accountable. In such a context, a man's qawãmah over women in terms of power relationship does not change accordingly, unless a woman wishes to apply for a divorce.

On the other hand, while the principle of qawãmah is applicable to both the domestic and the public spheres according to the fatwa of 1981, the current official MB position is that qawãmah is only applicable to martial relations. 'The boundaries of men's qawãmah over their wives is restricted to marital partnership only and it is a qawãmah of sincerity and mercifulness and consultation in return for responsibilities born by the husband'. By narrowing the sphere of the exercise of men's qawãmah over women to marital relations in the contemporary Muslim

Brotherhood's discourse, the question of women's occupation of leadership positions also shifts but not automatically. If men exercise their qawãmah at home to restrict women's sphere of influence and leadership to the household (vis-à-vis domestic responsibility), then the scope for agency outside the home is limited. This is a critical issue which some members of the Islamic movement face when they marry. In some cases, husbands have insisted that their spouses, highly active members of the movement prior to marriage, shift their energy into domestic responsibilities. Hence, in such circumstances, women's exercise of full agency may be, under certain circumstances, severely hindered by the underlying ideologically framed gender division of roles and its manipulation by some members to advance their own personal agendas. ${ }^{13}$

The fact that qawãmah is restricted to the private sphere means that women are not denying categorically the possibility of holding leadership positions over men. Women are allowed to hold a variety of positions, including that of Member of Parliament and Shura and minister provided a number of conditions are met (to be discussed later). In other words, they are allowed to not only vote but run for particular offices. The role of female members of the Muslim Brotherhood in the national parliamentary elections was instrumental for securing the victories that they have achieved, including in the last elections of 2005. It was the women members of the Muslim Brotherhood who, with their access to people via mosques (in particular the women's section of the mosques), the welfare organisations and access to homes, created a constituency and mobilised them to support the Brotherhood. In addition to their pivotal role in outreach in the wider community, women's votes represented a significant bulk of the votes that went to the Brotherhood. A recent study on women in the parliamentary elections of 2005 (Blaydes and Tarouti 2009) suggests that women have proven to be highly effective political recruiters for Muslim Brotherhood candidates. In addition, high turnout of veiled voters at women's polling stations creates common knowledge about the popularity of Islamist candidates in a particular district, and the presence of female activists cuts 
down on the likelihood and effectiveness of government repression. The participation of Islamist women in the face of repression and hardship also serves as a powerful and politically motivating symbol for both male and female voters who are inclined toward the Muslim Brotherhood (Blaydes and Tarouti 2009: 365).

The Brotherhood's support for women to run for political office has been more evasive. In the last elections of 2005, the Brotherhood only fielded one candidate, Makarem el Deiry for a middleclass Cairene electoral district. She lost and appealed against the results of the elections on the basis that there was vote rigging. The fact that the Brotherhood only fielded one woman out of many candidates fielded is not unique to the $\mathrm{MB}$, other political parties did not do much better, including the progressive leftist Tagammu party. ${ }^{14}$ Most political parties do not have politically seasoned women, and rarely would they have the kind of outreach that women members of the Muslim Brotherhood have via the religious and welfare services that are provided under the banner of the movement.

In view of the greater opportunities for political apprenticeship and leadership for Muslim Brotherhood women within the community compared with their counterparts in other political parties and forces, the pool of women who can potentially run for office, backed by a substantial constituency is greater and accordingly, the fact that so few are fielded by the Muslim Brotherhood is significant. It means that activist members have not been voicing a demand to assume leadership positions or that they have not collectively mobilised around this (the latter is the view expressed by El Deiry).

In an informal interview with a leading member of the Brotherhood vis-à-vis the forthcoming elections of 2010, in which a women's quota will be applied for the first time, he said that the difficulty is not in finding qualified women but that few women want to run. The problem, he argued, is that in view of the security harassments of Muslim Brotherhood candidates by the government, fielding a woman carries certain risks. A husband's or family's permission to allow women to field the elections is absolutely necessary if the MB were to extend support to a woman candidate, however, in view of the hardships entailed, such support is not always possible to secure. If a husband does not support his wife's candidature, then the Brotherhood cannot support her. The fact that support for women candidates is conditional upon a husband's consent indicates the way in which the concept of qawãmah at home is very much adhered to in daily policy and practice. However, equally significant is the extent to which the government's repression of the MB is undermining the spaces and opportunities for gendered transformations within the movement. Hypothetically speaking, if the Muslim Brotherhood was not subject to government repression, the justification for not rewarding capable women with more leadership opportunities would not have been so complacently accepted. In the absence of a political pretext to absolve the Brotherhood of their responsibility towards activist women, their real commitment to women assuming political leadership would have been tested.

By far the most renowned female figure in the history of the Muslim Brotherhood was Zeinab el Ghazali (2 January 1917-8 August 2005) who divorced her first husband because he came in the way of her da'wa (prosletising mission) and who was subject to extreme forms of torture under the Nasserite regime in the 1960s as a consequence of her activism. ${ }^{15}$ Yet for Hoda Abdel Moneim, Camillia Helmy and Makarem el Deiry, they viewed Zeinab el Ghazali as an exceptional figure and insist that not all women are called to become like her. From the conversations above, it became clear that while Zeinab el Ghazali is one of the most exonerated leaders for her courage, defiance and commitment to the Brotherhood, her experience serves as a harsh reminder of government cruelty, rather than as an example to be emulated. Yet while el Ghazali was highly respected within the Brotherhood, she was never a member of the Guidance Bureau. Today, none of the 17 members of the Guidance Bureau are women. When asked as to the reason behind their absence, the answer given by Habib and others is that putting women in leadership positions would make them more conspicuous to the ruling authority. However, there are questions as to whether this is a form of protection or a systematic exclusion from power. In other words, the full agency of women political activists in the MB is not only limited by the contextual dynamics, but also by an ideological salaf $i^{16}$ position shared by an overwhelming majority of its members of the movement, as Abd el Latif observes: 
The conservative view is that women can best serve the cause through their traditional roles as mothers and wives but not as political actors or peers in the movement. Consequently efforts to expand the role of the Sister activists in movement structures and political activities meet determined resistance, particularly from members living outside the capital. This conservative culture is being challenged to some extent by the younger generation of Brothers in the cities, but this group is a minority. Although they receive some encouragement from the reform-minded wing of the Brotherhood, they are frustrated. It appears that the majority of rank and file of both sexes hold a very conservative view of women's roles in the public sphere. (Abd el Latif 2008: 14)

It is significant that the contemporary MB standpoint is that there are certain positions that a woman is not allowed to hold, for example according to the Mubadara, women are prohibited from assuming the position of the Supreme Imamate 'and positions corresponding to it' ${ }^{17}$ i.e. the position that is equivalent to the highest leadership position in the country, such as President or Prime Minister, etc. ${ }^{18}$ Makarem el Deiry defended against the MB's prohibition of women holding the position of president on the basis that it relieves her of immense burdens and protects her from any possible harm. She suggested that wars are declared and waged by heads of governments (presidents) who sometimes have to engage in very bloody events. 'Hence, Islam does not want to expose her to any dangers or put her in a compromising position', she affirmed. Members of the reform wing in the Muslim Brotherhood such as Abou el Fotouh suggest that change of times in future may bring about a situation where it is permissible for women to hold the position of president (a position that he has openly advocated).

The position of the Muslim Brotherhood today is the prohibition of women from leading a Muslim country and is framed with strong paternalistic overtones of relieving women from undertaking a role for which nature has not equipped them:

For our part, we believe that the responsibilities required of the head of state, and these are responsibilities of wellaya [governance] and leadership of the army which are considered responsibilities that should not be imposed on women to shoulder because they conflict with her nature and her other social and human roles.

(Muslim Brotherhood Party Platform 2007: 103)

The above position suggests that the overall standpoint on gender roles delineated according to biological differences which was outlined by al-Banna many decades earlier continues to inform the Brotherhood's vision today. Despite this being the official position of the movement, while Abou el Fotouh has openly announced his rejection of such a stance thereby speaking the voice of the progressives to the outside world and affirming the external image that though the movement is heterogeneous, there continues to be progressive elements within it that will make the movement a 'moderate' one.

Yet it is unlikely that Abou el Fotouh's perspective will gain currency among the members of the rank and file of the Brotherhood or its leadership if the current political and sociocultural context remains unchanged. The Brotherhood's prohibition of women from leading the country is a position that is analogous with an opinion earlier expressed by Sheikh Ahmed el Tayeb, the former Grand Mufti of Al-Azhar, the country's leading Islamic establishment and one of the most renowned sources of authority for Sunni Muslims. When prominent Egyptian feminist Nawal el Saadawi announced that she would run for president in the presidential elections of 2004 (which she later retracted), the grand mufti of Egypt responded by issuing a fatwa (religious opinion) that prohibited women from assuming the position of president. Sheikh Ali Gomaa, the Grand Mufti later clarified that a woman could lead a modern Muslim state, although the earlier fatwa he had issued had already been widely disseminated and gained much ground. ${ }^{19}$

The objections expressed by the secularists to such a compromise on women's full citizenship in the MB Party Platform were weak - particularly in comparison to how vocal they were in their rejection of the Brotherhood's position on prohibiting non-Muslims from assuming the position of president. Moreover, despite a number of feminist activists' critiques, a weakened and fragmented feminist movement in Egypt failed to mobilise a unified collective 
platform to contest the Muslim Brotherhood's stance on women's assumption of political leadership of a country. (This was despite the fact that the Brotherhood's platform was widely discussed for a sustained and prolonged period of several weeks that had given them plenty of time for organising politically).

The MB's announcement of a political stance against women's right to hold the position of president did not only generate minimal opposition from political and civil society, but was in harmony with the religious-patriarchal normative ideals entrenched in contemporary Egyptian society. In a recent survey undertaken by the UNDP, only 45.9 per cent of Egyptians asked, believe women should have the right to become prime minister, and a mere 25.7 per cent believe women should have the right to become head of state. ${ }^{20}$

\section{Reformed or reframed?}

The overall ideological foundation of the MB contemporary stance on gender issues has not changed: women and men have strictly defined social roles based on their sex. All matters relating to men's and women's status and responsibilities and duties derive from this vision: though the contemporary MB discourse no longer advocates the restricted presence of women in the public sphere. Perhaps the most important shift in the position of the Muslim Brotherhood has been in its delineation of the limits of qawãmah, restricting it to the private domain. The pertinence of this position shift lies in its ramifications on women's occupation of leadership positions which necessarily entail women's direction/leadership over women as well as men. Yet women's occupation of leadership positions excludes the presidency as well as the imamate in prayer, and is conditional upon the fulfilment of certain conditions (in terms of mode of conduct and appearance) as well as conditions guaranteed in society (no threats to women's modesty, etc.).

The above suggests that while some progress has been made in terms of a narrower definition of the application of qawãmah, as well as with respect to expanding women's freedom in the public sphere, still men's qawãmah in the private sphere can effectively prevent women's participation in the public sphere, in terms of work or occupation of leadership positions. What this suggests is that a fundamental reform in their gendered approach to the position of women has not taken place. The MB's approach contests the notion that they are committed to the principles of universal citizenship since there are crucial challenges to the concept of women's political rights. In this respect, widening the scope of women's inclusiveness in the public realm still falls significantly short of even securing the modicum of rights that women in Egypt currently enjoy in the constitution, which is gender blind vis-à-vis the gender of the head of state.

If the agenda has not been reformed, it has been reframed in multiple ways. First, there is a far more sophisticated framing of arguments in a way that draws on political discourses in vogue. Hence, rather than framing positions in terms of 'it is prohibited for women to do $\mathrm{x}$ or $\mathrm{y}$ ', it is now framed in terms of a human rights discourse women's right to enjoy the benefits of men's qawãmah; women's right to protection from assuming roles incompatible with their biological nature, which is also simultaneously framed in a paternalistic discourse of protecting women.

There are several dynamics from which to shed light on the current standpoint - both internal and external. Internally, it is the conservative wing of the Brotherhood and one which has the greatest support among the rank and file that has the most power in the Guidance Bureau. It is likely to continue to remain faithful to the mainstream doctrine regarding gender hierarchies and divisions of labour, both of which favour men. The liberal faction is quite sidelined for the time being, so its prospects of influence have been contained. Moreover, women members of the Muslim Brotherhood have been excluded from holding significant posts of power within the movement, with no representation in the Guidance Bureau at all, historically or at present. Even if they were to resume positions of power, it would all depend on who is represented, since many women do adhere to the current doctrine, even if their personal lives betray clear deviations from the official stances.

Concurrently, a number of external factors have served to undermine the current prospects for revision and flexibility within the movement: these include government repression; a society where the social and political culture has been heavily influenced by Salafi thinking in particular 
vis-à-vis gender issues and which the Muslim Brotherhood has contributed towards through the promotion of a process of Islamisation of society from below, and the absence of an organised force of significant political weight, internal or external that would push the Brotherhood to reconsider the political

\section{Notes}

1 See The Moderate Muslim Brotherhood on the Brotherhood's website: www.ikhwanweb.com/ article.php?id=2107 (accessed 18 October 2010).

2 Hence, issues pertaining to reproductive health, social customs and family matters are discussed in a longer, future article.

3 The founder of the Muslim Brotherhood (MB).

4 Translated from Arabic to English by the author.

5 These include an interview with the former Supreme Guide and Muhammad Mahdi Akef, and former first deputy and member of the Guidance Bureau Muhammad Habib. Leading women members of the Muslim Brotherhood were also interviewed such as Makarem El Dery, professor of Arabic literature at Al-Azhar University and the only female member of the movement fielded in the 2005 parliamentary elections. Also interviewed was Camillia Helmy, an engineer who is also the director of the International Islamic Committee for Woman and Child which is an affiliate of the International Islamic Relief Committee. She is one of the most active women in the Muslim Brotherhood together with Hoda Abdel Moneim, a lawyer, activist and one of the leading women in the movement who was also interviewed. Close advisors to the Muslim Brotherhood were also informally interviewed.

6 For Western and Western-affiliated consumers, there was also the English website, which again had content packaged and selected differently from its Arabic counterpart. The material published on the English website is of a more generic nature under the section on 'Women and Islam', with a focus on showing that the Muslim Brotherhood are committed to the principle of equality. In the Arabic version on the other hand, there are clearer stipulations on the kind of policies that the MB advocate vis-à-vis reforming social relations. The tone is less apologetic, and the focus is on their agenda rather than the sacred textual position on women.

7 Despite the fact that these figures' writings do not hold the 'official endorsement', there is no repercussions of non-reform, in other words a force to be reckoned with. While the active agency of a minority of women affiliated to the Muslim Brotherhood in pressing for progressive change is not to be overlooked, it would be naive to underestimate the ideological and political odds against them at this historical conjuncture.

doubt however, that many hold significant power and legitimacy in the eyes of the rank and file and hence, excluding their ideas and perspectives ultimately means disregarding the voices of leaders who have shaped the ideology and policy of many members of the movement, however, this will be tackled in a future article.

8 The word he used is fash $i$ and it was removed in the edited version of this article, which appeared in the collection of his articles that was published by the second largest publishing house owned by the Muslim Brotherhood Dar el Da'wa (Al-Banna 1990: 304). The removal of the word does not indicate that his reverential position in the movement is challenged (the MB held a grand event in 2006 to mark 100 years since his birth), only that there is a more conscious attempt to 'repackage' his ideas to make them more palatable to a wider audience today.

9 See, for example the struggle led by Doria Shafik, which including going on a strike in the journalists' syndicate until Egypt's constitution recognises women's rights to political participation and representation. 10 El Da'wa (1981) Issue no 58, Cairo, Egypt.

11 The Mubadara addressed issues relating to the position and role of women in its tenth point. 12 Interview with Camillia Helmy, June 2005.

13 This is also an issue that was critiqued by renowned Sheikh Yusuf el Qaradawy, a figure held in high esteem by the Brotherhood and one of the informal leaders of the movement. See www.witnesspioneer.org/vil/Books/ Q_Priorities/ch2pl.htm\#A\%20Potential\% 20Objection\%20and\%20Its\%20Rebuttal (accessed 16 October 2010).

14 See Tadros and Costa (2010) 'Quotas: A Highway to Power in Egypt', in 'Quotas: Add Women and Stir', IDS Bulletin 42.1.

15 See Cooke (2001) for an interview with El Ghazali.

16 A faction within Sunni Islam that emerged in Saudi Arabia and has spread worldwide to advocate for a return to the way of life at the 
time of the Prophet Mohammed and his companions. It prescribes a most conservative ideology vis-à-vis gender issues in particular.

17 Translated from the Arabic ma fi hokmaha.

18 Although only the government leadership position is prohibited to women, there are other positions too from which women are prohibited such as leading men in prayer as Imam. All members of the Muslim Brotherhood confirmed that a woman cannot

\section{References}

Abd el Latif, Omayma (2008) In the Shadow of the Brothers: The Women of the Egyptian Muslim Brotherhood, Carnegie Papers 13, Washington DC: Carnegie Endowment for International Peace

Al-Banna, Hassan (1990) Rasa'el al Immam Hassan al Banna [Messages from the Imam Hasan alBanna], Alexandria: Dar el Da'wa

Al-Banna, Hassan (1980) 'Resalet al mar'a al muslima', in Muhammad Nasser el Din Al Albani (eds), Al Mar'a al-Muslima [Message to the Muslim Woman], Beirut: Dar el Jeel

Blaydes, Lisa and Tarouti, Safinaz (2009) 'Women's Electoral Participation in Egypt. The Implications of Gender for Voter Recruitment and Mobilization', Middle East Journal 63.3: Summer

Brown, Nathan J.; Hamzawy, Amr and Ottaway, Marina (2006) Islamist Movements and the Democratic Process in the Arab World: Exploring the Gray Zones, Washington DC: Carnegie Endowment for International Peace

Choubaky, Amr (ed.) (2006) 'The Muslim Brotherhood's and the Justice and Development Party's experiences', in Islamists and Democrats Problematics of Building a Democratic Islamist Force, 2nd edn, Cairo: Al-Ahram Centre for Strategic and Political Studies

Cooke, Miriam (2001) Women Claim Islam, London: Routledge

El Da'wa (February 1977) Cairo, Egypt, Vol. 26.9

El Deiry, Makarem (2007) 'Women in the literary output of Hassan al-Banna', in The Reformist Project of Hassan al-Banna: Questions for the Next Century, Cairo: Arab Media Centre Publishers

Hamid, Shadi (2007) 'Engaging Political Islam to Promote Democracy', Progressive Policy Institute lead men into prayer. Habib made the concession that she can preach to men, as Aisha, the wife of the Prophet did but that she cannot act as imam because there is an order in prayer in which men are to be in front followed by young boys, then women.

19 See Tadros (2010) http://freedomhouse.org/ template.cfm?page $=384 \&$ key $=253 \&$ parent $=$ $24 \&$ report $=86$

20 See UNDP (2006).

Policy Report, www.ppionline.org/documents/ Political_Islam_06272007.pdf (accessed 12 October 2010)

Hamzawy, Amr (2005) The Key to Arab Democracy: Moderate Islamists, Carnegie Endowment for International Peace, Policy Brief 40, August

Ibrahim, Saadeddin (2006) 'The "New Middle East" Bush is Resisting', Washington Post, 23 August, www.washingtonpost.com/wp-dyn/ content/article/2006 (accessed 21 October 2006)

Muslim Brotherhood (2007) MB Party Platform, Egypt

Muslim Brotherhood (2006a) Al Mubadara, http://ikhwanweb.com/home (accessed 1 June 2010)

Muslim Brotherhood (2006b) The Role of Muslim Women in an Islamic Society and the Stand of the Muslim Brotherhood Regarding Women's Rights to Vote, be Elected, Occupy Public and Governmental Posts, and Work in General, www.ikhwanweb.com/ Home.asp?zPage $=$ Systems\&System $=$ Press $\mathrm{R} \&$ Press $=$ Show $\&$ Lang $=\mathrm{E} \& \mathrm{ID}=3787$ (accessed 20 August 2007)

Rashwan, D. (ed.) (2006) Daleel al Harazakat al Islamiya fi al Allam, 2nd edn, Cairo: Centre for Political and Strategic Studies

Tadros, M. (2010) 'Egypt Country Report', The Women's Rights in the Middle East Freedom House Report 2010, www.freedomhouse.org/ template.cfm?page $=444$

UNDP (2006) The Arab Human Development Report 2005: Towards the Rise of Women in the Arab World, New York: UNDP: 94-261, http://hdr.undp.org/ en/reports/regionalreports/arabstates/RBAS_ ahdr2005_EN.pdf (accessed 1 October 2010)

Wickham, Cārrie, R. (2002) Mobilizing Islam, New York: Columbia University Press 